\title{
PERAN DAN AKTIVITAS PEREMPUAN ERA MUHAMMAD SAW (STUDI ATAS HADIS-HADIS RIWAYAT SAHABAT PEREMPUAN)
}

\author{
Zunly Nadia \\ STAISPA Yogyakarta, zunlynadia5@gmail.com
}

\begin{tabular}{l|l|l|} 
Diterima: 06 April 2020 & Direvisi : 10 Juni 2020 & Diterbitkan: 30 Juni 2020 \\
\hline
\end{tabular}

\begin{abstract}
This paper shows how the role of women both in the public and domestic area in the era of phrophet Mohamamd. In this case, the paper focus on woman companion transmitter who are directly wrapped up in the missionary work with the prophet. In addition, the paper will show the relation between woman companion transmitter activity and their hadis transmission, under assumtion that the role of woman will influence to the hadis texts which are transmitted. This because, as a text, hadis was transmitted in the certain context and condition. Accordingly, every transmitter had different hadis transmission based on his/her context, status, profession, and even gender construction. This is why, the paper will write the woman companion transmitter who play their role and their activity influence their hadis transmission.
\end{abstract}

Keyword: women transmitters, women companions, hadis

Artikel ini memperlihatkan bagaimana peran perempuan pada masa Nabi Saw, baik itu dalam wilayah publik maupun domestik. Dalam hal ini, tulisan ini fokus pada periwayat perempuan era sahabat yang terlibat langsung dan berperan dalam dakwah awal Nabi Saw. Lebih jauh lagi, artikel ini akan memperlihatkan bagaimana relasi antara aktifitas periwayat perempuan dengan hadis yang mereka riwayatkan dengan asumsi bahwa peran dan atau aktifitas periwayat perempuan tersebut akan mempengaruhi hadis-hadis yang mereka riwayatkan. Hal ini karena sebagai sebuah teks, hadis diriwayatkan dalam konteks dan kondisi tertentu. Oleh karena itu setiap periwayat memiliki periwayatan hadis yang sesuai dengan konteks, status, profesi dan bahkan konstruksi gender mereka. Dari sini kemudian, artikel ini akan menulis tentang peran dan aktifitas sahabat perempuan periwayat hadis yang berpengaruh terhadap hadis yang diriwayatkannya

Kata kunci: periwayat perempuan, sababat perempuan, hadis

\section{Latar Belakang}

Berbicara tentang peran perempuan, setidaknya ada dua macam peran yang dikenal selama ini, yakni yang pertama, peran publik yang juga disebut sebagai peran sosial dan kedua adalah peran domestik.Peran publik diartikan sebagai peran dalam masyarakat, baik dalam rangka mencari nafkah, maupun dalam mengaktualisasikan diri di berbagai bidang baik sosial, ekonomi, politik, agama dan lain sebagainya.Sebaliknya peran domestik dimaknai sebagai peran dalam keluarga atau rumah tangga, yang dalam konteks perempuan adalah sebagai istri atau ibu.

Dalam sebuah masyarakat, apalagi masyarakat dengan sistem patriarkhi, sebuah peran biasanya terkait dengan persoalan gender. Seseorang yang dilahirkan dengan kategori laki-laki dan perempuan, maka secara tidak langsung peran merekapun telah ditentukan dengan mengkondisikannya berperan sebagai seorang laki-laki atau 
perempuan. ${ }^{1}$ Sehingga peran gender disini adalah seperangkat harapan tentang prilaku apa yang pantas dilakukan seseorang dalam masyarakat berdasarkan identitas yang dimilikinya. Sosok perempuan lebih identik dengan peranannya di wilayah domestik (keluarga dan rumah tangga), sebaliknya lakilaki identik dengan peranannya di wilayah publik daripada wilayah domestik.

Era Nabi Muhammad yang ditandai dengan kehadiran Islam di jazirah Arab telah memberikan warna baru dan memberikan perubahan bagi kehidupan masyarakat Arab, yang salah satu diantaranya adalah pembelaan terhadap hak-hak perempuan. Beberapa peristiwa membuktikan adanya perhatian dan keberpihakan Muhammad terhadap perempuan, yang boleh jadi merupakan tindakan revolusioner pada masa itu. Misalnya pemberian hak waris terhadap perempuan, perempuan yang sebelumnya justru menjadi obyek yang diwariskan malah mendapatkan harta warisan, meski hanya separo dari bagian laki-laki.Nabi Muhammad juga tidak segan untuk mempercayakan sesuatu kepada perempuan yang menurut adat dan tradisi Arab tidak lazim. Seperti mempercayakan Rubayyi' bin Mu'awwizh ${ }^{2}$ dan Umm Athiyyah ${ }^{3}$ sebagai perawat korban yang luka dalam peperangan disamping bertugas sebagai juru masak dalam medan perang. Bahkan Nabi juga pernah memerintahkan seorang perempuan (Umm Waraqah) untuk menjadi imam shalat di lingkungan keluarganya. ${ }^{4}$ Contoh-contoh

1 Peran secara etimologis berarti laku atau bertindak. Peran didefinisikan sebagai serangkaian perilaku yang diharapkan pada seseorang sesuai dengan posisi sosial yang diberikan baik secara formal maupun informal, yatu serupa serangkaian hak, kewajiban, harapan, norma dan perilaku seseorang yang harus dihadapi dan dipenuhi. http//kbbi.web.id/peran2.

2 Muhammad Ismail Bukhari, Shabih al-Bukhari, jilid 6, (T.tp: Dar wa Mathabi' al-Sya'b, T.th), hlm 460

3 Ibn Hajjaj Muslim, Shabih Muslim, julid V, (Kairo: al-Halabi wa Auladuh, T.th), hlm 199

${ }^{4}$ Lihat Imam Abu Dawud, Sunan Abi Dawud, jilid I, hadis no.500,(Beirut: Dar al-Kutb al-Ilmiyyah, T. th), hlm 396-397. Lihat juga Ahmad ibn Hanbal, tersebut memperlihatkan bagaimaan peran perempuan dilibatkan dalam persoalanpersoalan persoalan publik dan kemasyarakatan oleh Nabi Saw pada masa itu.Sehingga tidak mengherankan jika beberapa perempuan sahabat Nabi tercatat sebagai orang yang aktif dan banyak meriwayatkan hadis. ${ }^{5}$

Tulisan ini akan berusaha menunjukkan bagaimana peran dan aktivitas perempuan pada masa era muslim awal, yang terlihat di dalam hadis-hadis yang diriwayatkan oleh sahabat perempuan. ${ }^{6}$ Dari sini kemudian, tulisan ini akan memaparkan para sahabat perempuan yang berkiprah dalam berbagai ruang publik, baik itu bidang politik, sosial, ekonomi dan lain sebagainya sebagaimana yang dijelaskan di dalam hadis-hadis yang mereka riwayatkan.

\section{Hasil dan Pembahasan \\ Mengenal Sahabat Perempuan Periwayat Hadis}

Kata sahabat berasal dari bahasa Arab “al-shahabah"yang berarti teman bergaul, sahabat, teman duduk, penolong, pengikut. Definisi dan konsep tentang sahabat Nabi bukanlah konsep tunggal, melainkan terdapat beberapa definisi tentang sahabat. Hal ini dikarenakan terutama konteks hadis posisi sahabat sangat penting, dimana hadis sebagai hasil dari periwayatan dan sumber hukum kedua setelah al-Qur'an pasti melibatkan para

Musnad al-Imam Ahmad ibn Hanbal, jilid VI, hadis no 26023, (Beirut: Dar al-Fikr, T.th) hlm 405

5 Misalnya Asma' binti Abi Bakar yang meriwayatkan 209 hadis, Zainab binti Abi Salamah yang meriwayatkan 177 hadis, Nusaibah binti Ka'ab yang meriwayatkan 119 hadis, Shafiyah binti Syaibah meriwayatkan 106 hadis, Fathihah binti Abi Thalib meriwayatkan 87 hadis, Fathimah binti Qais yang meriwayatkan 86 hadis, Asma binti Yazid yang meriwayatkan 76 hadis, Lubabah binti al-Haris meriwayatkan 48 hadis, Al-Rubayyi' binti Mu'awwidz yang meriwayatkan 44 hadis, dan masih banyak lagi para sahabat perempuan yang meriwayatkan hadis dari Nabi Saw. 
sahabat dalam proses transmisinya. Generasi sahabat adalah orang-orang yang menerima ajaran Islam langsung dari Nabi Muhammad. Mereka juga orang-orang yang menyaksikan turunnya ayat-ayat al-Qur'an. Tanpa generasi sahabat, umat Islam belakangan tidak akan mengetahui apa-apa tentang Islam. ${ }^{7}$

Adapun definisi sahabat yang paling banyak dipakai oleh jumhur ulama adalah definisi sahabat yang didefinisikan oleh Ibnu Hajar al-Asqalani,yakni siapa saja yang pernah bertemu dengan Nabi Saw (laqiya), beriman kepadanya (amana) dan meninggal dalam keadaan Islam (wa mata 'ala islamib). ${ }^{8}$ Definisi ini menurut Fuad Jabali adalah definisi yang paling komprehensif. Term laqiya disini sudah termasuk di dalamnya bersama dengan Nabi dan mengikuti majelis-majelis Nabi. Adapun amana disini berarti tidak termasuk sahabat, orang yang beriman setelah wafatnya Nabi, atau yang disebut dengan al-mubadramin dan term mata 'ala islamih berarti tidak termasuk sahabat yang murtad dan tidak muslim kembali. ${ }^{9}$

Jumlah perempuan periwayat hadis dalam kitab hadis al-kutub al-tis'ah berjumlah 328 periwayat dengan jumlah periwayat pada thabaqah sahabat tercatat sebagai periwayat perempuan terbanyak jika dibandingkan dengan thabaqah-thabaqah sesudahnya, yakni berjumlah 133 orang dari 1046 periwayat, ${ }^{10}$ kemudian periwayat perempuan

7 Ali Mustafa Yaqub, Kritik Hadis, (Jakarta: Pustaka Firdaus, 2008), hlm 104.

${ }^{8}$ Ibnu Hajar Al-Asqalani, al-Isabah fi Tamyiz alSahabah, (Mesir: al-Maktabah al-Tijjariyah, 1358), jilid I, hlm 10. 86-87.

${ }^{9}$ Fuad Jabali, The Companion of the Prophet....hlm

${ }^{10}$ Identifikasi awal ketika mencari para perawi hadis perempuan era sahabat ini di software Mausu<'ah, penulis menemukan 133 perawi perempuan. Ketika di cek satu persatu penulis menemukan dua nama yang sama yakni Furai'ah binti Malik bin Sinan, di mana Furai'ah binti Malik bin Sinan pertama tertulis saudara Abu Sa'id al-Khudry dan yang kedua tercatat dengan laqab Kabsyah. Setelah penulis cek pada hadis yang diriwayatkan, Furai'ah binti Malik yang pertama meriwayatkan 9 hadis dan yang kedua 2 hadis, dengan pada periode tabi'in senior (thabaqah kedua) berjumlah 30 orang dari 438 periwayat. Pada periode tabi'in pertengahan (thabaqah ketiga) berjumlah 93 orang dari 1.467 periwayat.Pada periode tabiin pasca pertengahan (thabaqah keempat) terdapat 36 orang periwayat perempuan dari jumlah 875 periwayat.Pada periode tabiin yunior (thabaqah kelima) terdapat 10 orang dari 576 periwayat. Pada thabaqah keenam terdapat 15 orang periwayat perempuan dari 1.119 orang. Pada periode atba' tabiin senior (thabaqah ketujuh) terdapat 11 orang periwayat perempuan dari 943 periwayat.Pada periode atba' tabi'in pertengahan (thabaqah kedelapan), thabaqat kesembilan, thabaqah kesepuluh dan thabaqah kesebelas tidak ada seorangpun perempuan tercatat sebagai periwayat hadis. ${ }^{11}$

Dilihat dari sisi kualitas periwayatan, kualitas para periwayat hadis perempuan ini juga tidak bisa diragukan lagi, dimana sebagian besar dinilai positif oleh para ulama jarh wa ta'dil, Az-Zahabi dalam kitabnya mengemukakan bahwa ia tidak menemukan satu perempuan pun yang tertuduh dusta dan ditinggalkan hadisnya. Kalaupun terdapat periwayat perempuan yang dikategorikan

isi dari matan hadis secara keseluruhan adalah sama, hanya saja berbeda kitab hadis, 9 hadis yang terdapat pada keterangan hadis yang diriwayatkan oleh Furai'ah pertama terdapat di dalam kitab Sunan Abu Da<wud, Tirmidri, Ibnu Majah, an-Nasa'i, al-Da>rimi dan alMuwat $\{$ a' Imam Malik. Sedangkan 2 hadis pada riwayat Furai'ah yang kedua terdapat di dalam kitab Musnad Ah\{mad, sehingga saling melengkapi. Agung Danarta juga menuliskan dalam disertasinya bahwa jumlah sahabat perempuan periwayat hadis berjumlah 132 orang. Lihat Agung Danarta, "Perempuan Periwayat Hadisdalam al-Kutub al-Tis'ab", Disertasi, Program Pasca Sarjana UIN Sunan Kalijaga Yogyakarta, 2007, hlm 186.

Namun demikian, terdapat perbedaan jumlah sahabat perempuan periwayat hadis di dalam kitab Ibnu H\}ajar yang berjumlah 126 periwayat. Beberapa nama periwayat perempuan era sahabat seperti Durrah binti Mu'ad, Imraatu Abi Sa'id al-Hudzri, Ummu Mazidah binti Jabir, Ummu Abdullan bin 'Atha, Walidah Abdurrahman bin T\{ariq dan Ummu Walad li Syaibah yang terdapat di dalam Mausu'ah tidak disebutkan oleh Ibnu Hajar di dalam kitabnya.

${ }^{11}$.Ibid., 
lemah, hal itu semata-mata karena tidak adanya informasi yang cukup memadai terkait dengan latar belakang kehidupan mereka. An-Nasa'I dalam al-Du'afa wa al-Matrukin, kitab yang memuat tentang perawi yang dhaif juga memperlihatkan bahwa dari sekian para perawi yang dhaif hanya ada satu perawi perempuan, itupun An-Nasai tidak menggunakan ungkapan kritik yang keras terhadapnya. Demikian pula dalam kitab-kitab jarb wa ta'dil karya ulama hadis yang lain. Hal ini memperlihatkan bahwa periwayat perempuan cukup diakui kualitas dan kredibilitasnya dalam periwayatan, apalagi dalam syarat-syarat keadilan periwayat hadis juga tidak terdapat ketentuan bahwa perawi harus berjenis kelamin laki-laki. ${ }^{12}$

Diantara para periwayat perempuan ini memperlihatkan bahwa terdapat sepuluh periwayat perempuan yang meriwayatkan hadis terbanyak, lima orang di antaranya adalah istri Nabi Saw, yakni Aisyah binti Abu Bakar yang meriwayatkan 1999 hadis tetapi di dalam kutub al-Tis'ah disebutkan sebanyak 5965 hadis, kemudian Hindun binti Abi Umayyah meriwayatkan 158 hadis yang disebutkan di dalam kutub al-Tis'ah sebanyak 622 hadis, Maimunah binti Haris meriwayatkan 31 hadis dan disebutkan di dalam kutub al-Tis'ah sebanyak 172 hadis, Hafsah binti Umar meriwayatkan 28 hadis dan disebutkan di dalam kutub al-Tis'ah sebanyak147 hadis, Ramlah binti Abi Sufyan yang meriwayatkan 29 hadis dan disebutkan di dalam kutub alTis'ab sebanyak 138 hadis. Selain istri Nabi, terdapat satu orang kakak ipar Nabi yakni Asma binti Abu Bakar yang meriwayatkan 42 hadis dan disebutkan di dalam kutub al-tis'ah sebanyak 209 hadis, sepupu Nabi, yakni Fakhithah binti Abi Thalib meriwayatkan meriwayatkan 22 hadis dan disebutkan di dalam kutub al-tis'ah sebanyak 87 hadis. Dari kesepuluh periwayat hadis terbanyak, hanya

12 Ali Muhanif (ed.), Perempuan dalam Literatur Klasik, (Jakarta: Gramedia, 2002), hlm 50. tiga periwayat yang tidak memiliki hubungan keluarga dengan Nabi, yakni Nusaibah binti Ka'ab (Ummu At\{iyah) yanng meriwayatkan sebanyak 52 hadis dan disebutkan di dalam kutub al-tis'ah sebanyak 119 hadis, Fatimah binti Qais meriwayatkan 20 hadis yang disebutkan di dalam kutub al-tis'ah sebanyak 86 hadis, al-Rubayyi' binti Mu'awwiz yang meriwayatkan 17 hadis dan disebutkan sebanyak 44 hadis di dalam kutub al-tis'ab. ${ }^{13}$

Jika dilihat dari tempat domisili, Madinah adalah tempat domisili mayoritas dari periwayat hadis perempuan, yakni 65 orang periwayat. Adapun lainnya Maru al-Radh sebanyak 6 orang periwayat, Basrah 3 orang periwayat dan Syam 2 orang periwayat, dan sisanya tidak diketahui. Hal ini bisa dimaklumi karena Madinah adalah pusat periwayatan hadis, disamping Madinah menjadi kota utama umat Islam semenjak Nabi Saw berhijrah dari Makkah hingga beliau wafat. Madinah juga menjadi pusat pemerintahan selama masa pemerintahan khulafaur Rasyidin.sehingga banyak sahabat yang tinggal di kota ini. Selain itu, terdapat beberapa shahabiyah yang berdomisili di satu kota dan meninggal di kota

13 Jumlah hadis yang diriwayatkan oleh para periwayat perempuan ini didapatkan dengan merujuk pada kitab al-Mizzi Tubfatul Atraf fi Ma'rifati al-Asyraf (Beirut: Dar al-Gharb al-Islami, 1999), juz XI dan juz XII. Sedangkan jumlah hadis yang disebutkan di dalam kutub al-tis'ah merujuk pada mausu'ah dimana jumlah hadis tersebut sudah termasuk pengulangan hadisnya. Nama 10 periwayat perempuan yang paling banyak meriwayatkan hadis ini berbeda dengan yang disebutkan oleh Agung Danarta dalam penelitiannya tentang perempuan periwayat hadis.Perbedaan ini terletak pada nama-mana seperti Zainab binti Abi Salamah dan Safiyyah binti Syaibah yang oleh Agung Danarta masuk dalam sepuluh besar periwayat perempuan yang banyak meriwayatkan hadis. Sedangkan dalam penelitian ini, keduanya tidak masuk dalam sepuluh besar periwayat perempuan yang banyak meriwayatkan hadis dan sebagai gantinya, terdapat nama Fatimah binti Qais dan Al-Rubayyi binti Mu'awidz. Perbedaan ini karena perbedaan rujukan, dimana Agung Danarta merujuk pada software mausu'ah sedangkan penulis merujuk pada kitab al-Mizzi dalam menentukan jumlah hadis yang diriwayatkan oleh periwayat perempuan. Lihat Agung Danarta, Perempuan Periwayat Hadis, (Yogyakarta: Pustaka Pelajar, 2013), 118-119. 
yang lain, diantaranya adalah Maimunah binti Haris yang berdomisili di Madinah dan wafat di kota Sarkhas, Asma binti Abu Bakar yang berdomisili di Madinah dan wafat di kota Maru al-Radh, Zainab binti Abi Salamah yang berdomisili di Madinah dan wafat di Maru AlRadh, Ummu Haram binti Malikan yang berdomisili di Madinah dan wafat di Kufah serta Fatimah binti Qais yang berdomisili di Madinah dan wafat di Fiid.

Jika dilihat dari kesukuan maka sahabat perempuan dari kalangan ansar (al-ansariyah) merupakan sahabat perempuan terbanyak yakni sebanyak 28 orang, dan kemudian disusul sahabat perempuan dari suku Quraisy (al-Qurasyiyah), yakni 12 orang. Dominasi perempuan ansar ini sebagai penduduk asli Madinah karena memang terkait dengan kota Madinah sebagai kota utama umat Islam masa itu. Sementara itu kaum Quraish sebagai pendatang dan suku di mana Nabi Muhammad berasal.

Jika dilihat dari tema-tema hadis yang diriwayatkan oleh sahabat perempuan ini, maka hadis-hadis fiqih terutama fiqih keluarga, fiqih tentang perempuan dan akhlak memang lebih banyak dibandingkan dengan hadis tentang muamalah dunyawiyah seperti hadis tentang perang/jihad. Hal ini akan kita lihat bagaimana hadis-hadis yang diriwayatkan oleh para sahabat perempuan ini sangat terkait dengan kondisi dan situasi para periwayat. Untuk lebih jelasnya, hal ini akan penulis paparkan pada bab selanjutnya. ${ }^{14}$

\section{Peran dan Aktivitas Sahabat Perempuan di dalam Ruang Publik}

Dalam sub bab ini, penulis ingin memperlihatkan bagaimana peran dan aktivitas perempuan pada masa Nabi Muhammad dilihat dari hadis-hadis yang mereka riwayatkan. Hal ini karena hadis memuat satu

${ }^{14}$ Tabel ini dibuat oleh penulis dengan melihat pada softwer Mausu'ah, yang memuat kitab-kitab hadis 9 (kutub al-Tis'ab). peristiwa dimana apa yang diriwayatkan oleh seorang periwayat pasti akan sesuai dengan apa yang mereka lihat dan lakukan pada masa itu. Disamping juga merepresentasikan bagaimana kondisi sosio kultur masyarakat pada masa Arab di era Nabi Saw. Sebagai seorang manusia biasa, seorang periwayat hadis tentu saja tidak akan bisa lepas dari konteks sosial masyarakatnya, dari cara bertindak, berfikir dan berinteraksi dengan lingkungan sosialnya, semuanya merupakan hasil dari pengaruh lingkungan disekitarnya, demikian pula sebaliknya. Beberapa aktivitas dan peran sahabat perempuan dalam masyarakat Arab berikut keterkaitannya dengan hadis-hadis yang diriwayatkan, diantaranya adalah sebagai berikut:

\section{Ikut dalam peperangan Aisyah Binti Abu Bakar}

Aisyah dikenal dengan gelarnya AshShiddiqah dan seringkali dipanggil dengan Ummu Abdullah. ${ }^{15}$ Nabi Muhammad sendiri terkadang memanggilnya dengan Humaira, yang merupakan julukan khusus kepada Aisyah yang tidak diberikan kepada istri istri Nabi yang lain. Hal ini merupakan salah satu tanda bagaimana Aisyah merupakan istri yang sangat spesial bagi Nabi Muhammad Saw.

Aisyah adalah sosok yang pemberani, kokoh dan tegar. Dia sering ikut terjun ke medan perang. Pada perang uhud, ketika kaum muslimin kocar kacir, Aisyah bersama kaum perempuan justru turun memberi minum orang-orang yang terluka, dan mengusung bejana air untuk diisi dan diminumkan kepada para mujtahid.Pada perang khadaq, dia turun

15 Ummu Abdullah adalah nama kunyah Aisyah yang diberikan oleh Nabi Muhammad. Nama kunyah ini biasa dimiliki oleh perempuan Arab. Abdullah adalah nama dari anak dari saudara Aisyah, Asma binti Abu Bakar. Hal ini karena Aisyah memang tidak dikaruniai keturunan selama hidupnya sehingga dia menggunakan nama kunyah ummu Abdullah karena dia menganggap Abdullah sebagaimana putranya sendiri. Lihat Sunan Abu Daud, bab al-Mar'ah Takni, no. 4970 dan Musnad Imam Ahmad, no. 26285. 
dari benteng melindungi Nabi Muhammad, para istri, anak-anak, maju ke barisan terdepan. ${ }^{16}$

Hadis yang diriwayatkan oleh Aisyah terkait dengan politik, diantaranya adalah : Kitab Shahih Bukhari no.3769

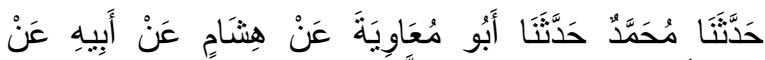

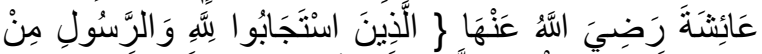

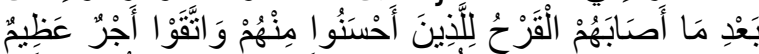

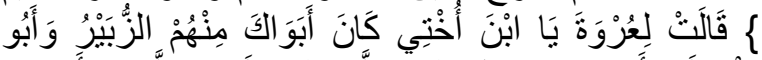

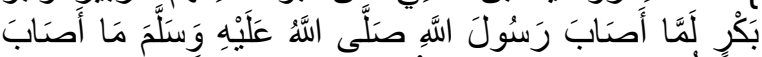

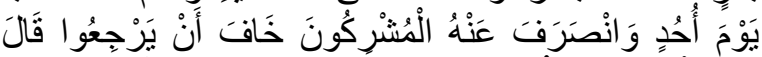

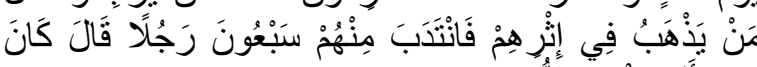

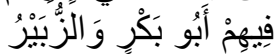

Kitab Hadis Shahih Bukhari, no. 2672

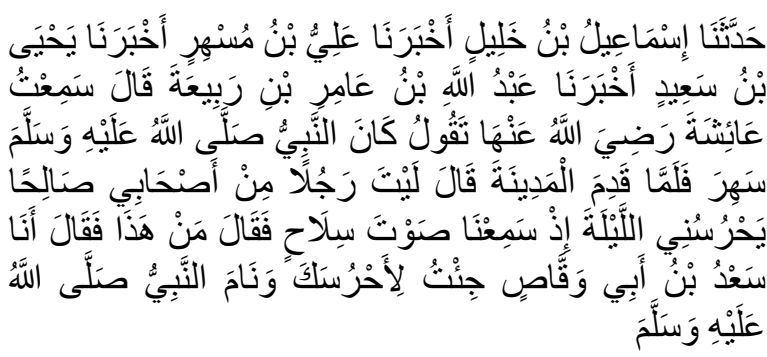

\section{Nusaibah binti Ka'ab.}

Nusaibah binti Ka'ab atau dikenal dengan Ummu Athiyah al-Anshariyah merupakan salah satu sahabat perempuan yang bukan dari keluarga Nabi Saw, tetapi masuk dalam daftar sepuluh sahabat perempuan yang banyak meriwayatkan hadis. Terdapat 119 hadis dalam kutub al-tis'ah yang disandarkan kepadanya.

Nusaibah binti Ka'ab atau Ummu Athiyah juga salah seorang sahabat perempuan yang terlibat dalam peperangan bersama Nabi Saw. Dia bertugas membuat makanan untuk pejuang muslimin, mengobati tentara yang terluka dan merawat yang sakit. Selain itu Ummu Athiyah adalah salah seorang sahabat perempuan yang berdomisili di Basrah,

16 Sulaiman al-Nadawi, Aisyah: Sejarah Lengkap Ummul Mukminin Aisyah RA, terj. (Jakarta: Qisthi Press, 2007), hlm 169 karenanya dia menjadi salah saru narasumber utama hadis Nabi Saw di kota Basrah. ${ }^{17}$

Hadis-hadis yang diriwayatkan oleh Ummu Athiyah disandarkan langsung dari Nabi Saw dan sebagian lainnya melalui Umar bin al-Khattab. Adapun yang meriwayatkan hadis darinya adalah Anas bin Malik, Muhammad ibn Sirin, Hafsah binti Sirin, Abdul Malik ibn Umayr, Ismail ibn Abdurrahman ibn Athiyah, Ali ibn al-Aqmar, dan Ummu Sarahil.

119 hadis yang diriwayatkan oleh Ummu Athiyah terdiri dari beberapa tema, yang termasuk dalam fikih dan perang. Hampir semua hadis yang diriwayatkan oleh Ummu Athiyah ini terkait dengan persoalan fikih seperti wudhu, haid, shalat, jenazah, zakat, haji, menerima hadiah, thalaq. Selain tentang fikih, beberapa hadis yang diriwayatkannya terdapat hadis yang terkait dengan baiat perempuan dan 5 hadis tentang perang/jihad. Shahih Muslim,kitabjihab wa siyar no. 3380

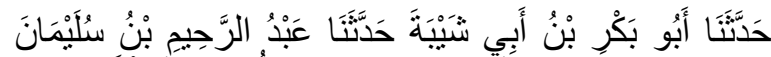

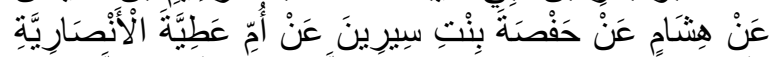

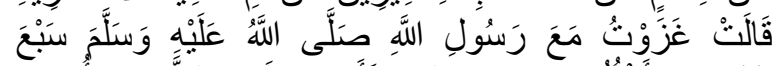

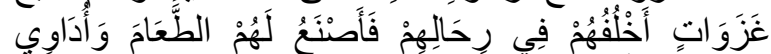

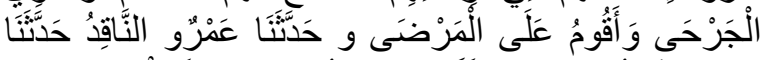

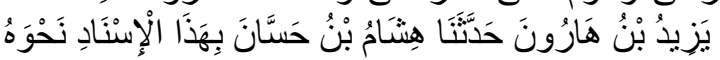

\section{Al-Rubayyi' binti Mu'awwidz}

Al-Rubayyi' binti Mu'awwidz dikenal sebagai salah seorang sahabat perempuan yang pemberani.Keberaniaanya ini juga dipengaruhi oleh ayahnya yang notabene adalah seorang yang bergabung dalam operasi pembunuhan abu Jahal.Al-Rubayyi' juga dikenal sebagai seorang sahabat perempuan yang mempunyai hubungan yang cukup dekat dengan Nabi Muhammad yang ditunjukkan dengan beberapa riwayat tentang kedatangan Nabi Muhammad ke rumahnya, juga pemberian hadiah dari beliau.

${ }^{17}$ Ibnu Hajar al-Asqalani, Tabdzib al-tahdzib, juz xii, hlm 455, lihat juga al-Isabah, jilid IV, hlm 477. 
Al-Rubayyi' meriwayatkan 44 hadis dari Nabi Muhammad yang beberapa diantaranya menceritakan tentang kiprahnya dalam politik, yakni ketika mengikuti perang bersama dengan pasukan muslim.

Beberapa periwayat yang menerima hadis dari Rubayyi' diantaranya adalah Abu Ubaidah bin Muhammad bin Abdullah, Khalid bin Dzikwan (Abu Husain), Sulaiman bin Yasar, Ubaidah bin Walid bin Ubadah bin alShamad (Abu Al-Shamat), Abdullah bin Muhammad bin 'Aqil bin Abi Thalib (Abu Muhammad), Muhammad bin Abdul Rahman bin Tsauban (Abu Abdullah), Nafi' maula ibn Umar (Abu Abdullah). Sedangkan Rubayyi' sendiri selain menerima hadis dari Nabi, dia juga menerma hadis dari Usman bin Affan.

Diantara hadis Rubayyi' yang terkait dengan kiprahnya di dunia politik adalah:

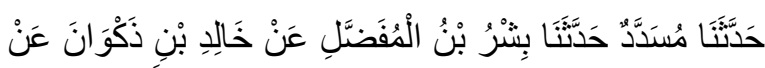

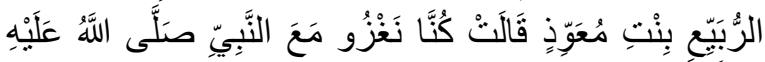

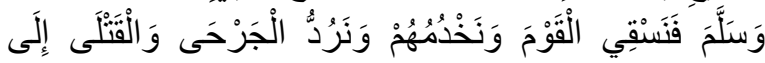

الََْدَينَة

\section{Ummu Haram bint Malihan}

Nama lengkapnya adalah Ummu Haram bint Malihan bin Khalid bin Zaid bin Haram bin Jundab bin 'Amir bin Ghanm bin 'Ady bin Ibn Najjar. Suaminya bernama 'Ubadah bin alShamat yang bersama sama dengan Ummu Haram berangkat ke medan perang. Ummu Haram merupakan bibi dari sahabat Anas bin Malik yang merupakan salah satu sahabat yang masuk dalam golongon pertama orang yang masuk Islam. ${ }^{18}$

Ummu Haram meriwayatkan 11 hadis dari Nabi Muhammad Saw, yang beberapa diantaranya hadis yang menyatakan akan kabar gembira dari Nabi bahwa kelak dia akan menjadi syahidah. Apa yang diberitakan oleh Rasulullah ini kemudian menjadi kenyataan karena pada masaMu'awiyyah bin Abu Sufyan,

${ }^{18}$ Muhammad bin Sa'adbin Mani' al-Zuhri, Kitab Thabaqaat al-Kabir,.....Ibid, hlm 40-405
Ummu Haram mengikuti peperangan bersama suaminya. Sesudah berlayar dan kembali ke daratan Ummu Haram diserang binatang tunggangannya hingga wafat.

Beberapa periwayat yang menerima hadis ari Ummu Haram adalah Anas bin Malik bin al-Nadhr bin Zaid bin Haram (Abu Hamzah), Atha bin Yasar (Abu Muhammad), Amru bin Aswad (Abu 'Iyadz), Ya'la bin Syadad bin Aws (Abu Tabit).

Diantara Hadis yang menyatakan tentang kiprahnya di dunia politik adalah:

Kitab Shahih Bukhari, no. Hadis 2707

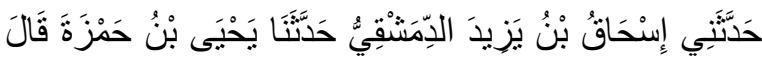

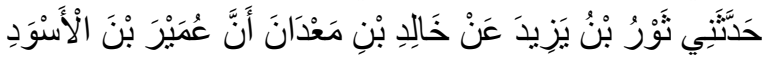

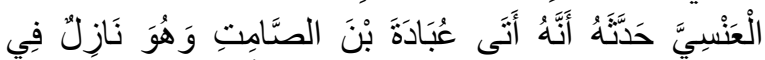

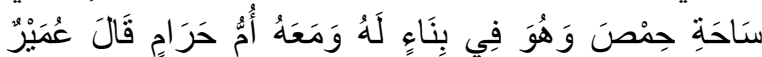

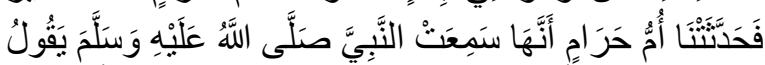

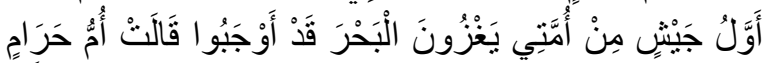

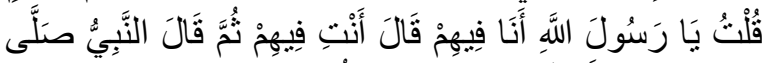

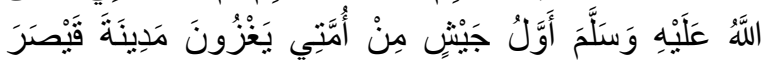

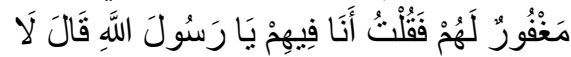

Kitab Shahih Bukhari, no. Hadis 2680

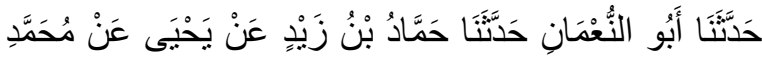

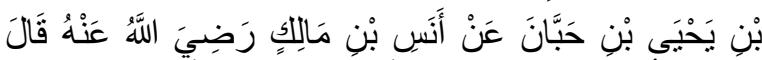

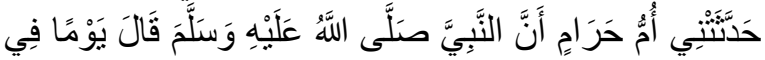

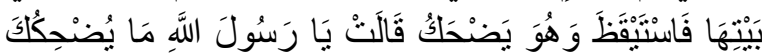

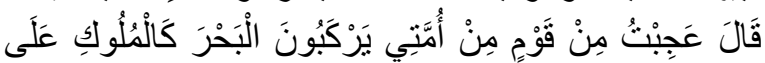

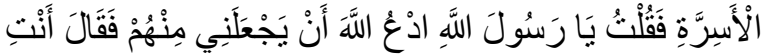

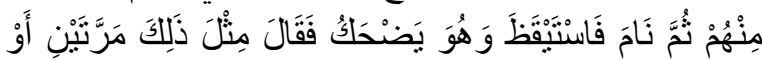

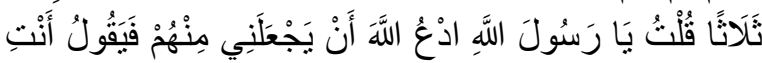

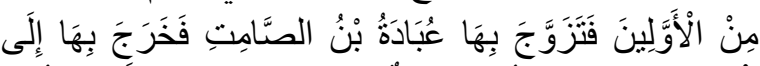

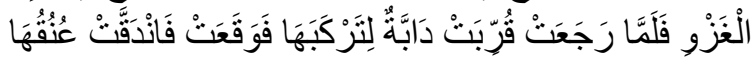

\section{Negosiator dan ahli strategi}

Sahabat perempuan periwayat hadis yang terlibat dalam persoalan politik sebagai ahli negosiasi adalah Ummu Hani.Beliau adalah sepupu dari Nabi Muhammad Saw.Ia 
pernah memberikan jaminan keamaan kepada beberapa orang musyrikin (jaminan keamanan merupakan salah satu aspek bidang politik). Sikapnya ini dibenarkan oleh Nabi Saw. Ummu Hani', nama lengkapnya adalah Fakhitah binti Abi Thalib. Ia dilahirkan di Madinah. Ayahnya Abu Thalib bin 'Abdul Muthalib bin Hasyim bin Abdi Manaf bin Qushay. Sedangkan ibunya adalah Fatimah binti Asad bn Hasyim bin Abdul Manaf bin Qushay. Kemudian ia menikah dengan Hubairah bin Abi Wahab al-Mahzumy. ${ }^{19}$ Hubungan kerabat dengan Nabi Saw menjadikan ia sebagai periwayatkan hadis dengan jumlah hadis cukup banyak, yakni ia meriwayatkan 87 hadis dari Nabi Saw. Beberapa periwayat yang mengambil hadis darinya adalah Abu Shalah, Ju'dah, Abd Rahman bin Abi Laily, Abdullah bi Haris, Abullah bi Abbas, Abdullah bi Abdullah bi Haris, 'Urwah bin Zubair, Atha' bin Abi Rabah, Mujahid bi Jabar, Muhammad bin 'Aqabah, Harun ibn Ummu Hani', Yahya bin Ju'dah, Yazi bin Maula 'Aqil, Yusuf bin Mahik.

Diantara hadis yang diriwayatkannya adalah hadis tentang yang pemberian jaminan kepada kaum musyrikin.

Abu Dawud, Kitab Jihad, bab Fi Amani almar'ah, no.2382

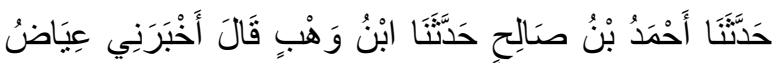

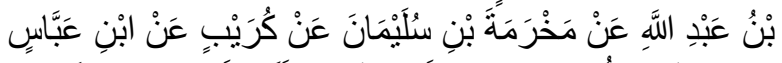

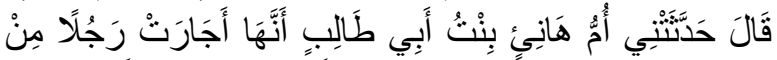

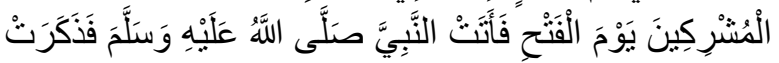

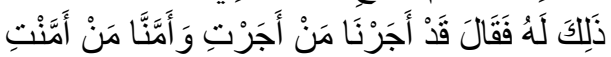

\section{Guru menulis dan ahli Ruqyah As-Syifa binti Haris}

Nama lengkapnya adalah asy-Syifa' binti Abdulloh bin Abdi Syams bin Kholaf bin Sadad bin Abdulloh bin Qirath bin Rozah bin Adi bin Ka'ab al-Qurosyiyyah al-Adawiyah.

1919 Muhammad bin Sa'adbin Mani' al-Zuhri, Kitab Thabaqaat al-Kabir, (Kairo: tp,t.th) hlm 47-48
Berdomisili di Madinah, Asy-Syifa termasuk sahabat perempuan yang masuk Islam sebelum hijrahnya Nabi Saw dan termasuk muhajirin angkatan pertama dan termasuk wanita yang berba'iat kepada Nabi Saw. Asy-Syifa' termasuk wanita yang cerdas dan dikenal sebagai guru dalam membaca dan menulis sebelum datangnya Islam, sehingga ketika dia masuk Islam,dia memberikan pengajaran kepada wanita-wanita muslimah dan disebut sebagai 'guru wanita pertama dalam Islam'. Di antara wanita yang dididik oleh asy-Syifa' adalah Hafshah binti Umar bin Khotthab istri Nabi Saw. ${ }^{20}$

Selain sebagai guru membaca dan menulis asy-Syifa' juga dikenal sebagai ahli ruqyah di masa Jahiliyah. Ketika masuk Islam, ia memperlihatkan kemampuannya kepada Nabi Saw, dan Nabi memperbolehkan dan bahkan mengajarkannya di kalangan kaum muslimin. Ia juga sering diutus Nabi untuk menjelaskan tentang Islam dan memberi nasehat kepada kaum muslimin. Karena kecerdasan dan kepandaiannya dalam urusan agama dan dunia, maka Umar bin Khatab sering mendahulukan pendapat al-Syifa. ${ }^{21}$ maka tidak mengherankan jika hadis-hadis yang diriwayatkannya juga terkait dengan ruqyah. Di antara yang meriwayatkan hadis dari As-Syifa adalah putranya yaitu Sulaiman dan cucucucunya, hamba sahayanya yaitu Ishak dan Hafshah Ummul Mukminin dan lain-lain.AsSyifa meriwayatkan 4 buah hadis dan dua diantaranya adalah hadis tentang ruqyah.

Sunan Abu Dawud bab al-Thib no hadis 3389

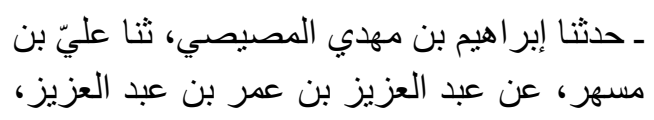

${ }^{20}$ Abu Syuqqah, Tahrir al-Mar'ah, juz II, hlm 346.

21 Telah diriwayatkan dari Umar bin al-Khattab bahwa ia pernah mengangkat al-Syifa' "seorang perempuan dari kaumnya" untuk menangani persengketaan di pasar yakni sebagai qadhi hisbah yang memutuskan semua persengketaan yang terjadi." Taqi al-Din al-Nabhani, al-Nidzam al-Ijtima' fi al-Islam, hlm. 139; Abu Syuqqah, Tabrir al-Mar'ah, juz II, hlm.390. 
عن صالح بن كيسان، عن أبي بكر بن سليمان بن

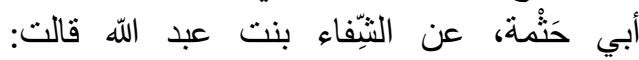
دخل عليَّ رسول الله صلى الله عليه وسلم وأنا عند حفصة، فقال لي: "ألا تعلمين هذه رقية النملة كما علمتيها الكتابة؟" لانهية

\section{Menyiapkan perbekalan dan Pengantar} Makanan

\section{Asma binti Abu Bakar}

Asma binti Abu Bakar, adalah putri dari khalifah Abu Bakar ini adalah seorang sahabat perempuan yang berani mengantarkan makanan kepada Nabi Saw di Gua Tsur, ketika semua orang takut berhubungan dengan Nabi Muhammad Saw. Asma adalah isteri dari Zubair bin Awwam, salah seorang sahabat yang dijamin masuk surga.

Asma' binti Abu Bakar meriwayatkan 209 hadis dari Nabi Saw. Banyaknya hadis yang diriwayatkan karena hubungannya yang cukup dekat dengan Nabi Saw.Hadis-hadis yang diriwayatkannyapun cukup beragam, mulai dari persoalan fikih, sosial hingga persoalan politik. Beberapa periwayat yang meriwayatkan hadis darinya adalah Abu Bakar bi Abdullah bin Zubair, Bakr bin Amr, Shafiyah binti Syaibah, 'Ibad bin Hamzah, 'Ibad bin Abdullah, Abdullah bin 'Ubaidillah, Abdullah bin Kaisan, Urwah bin Zubair, Fatimah binti Mandzur, Mujahid bin Jabar, Muhammad bin Muslim bin Ubaidillah, Muslim bi Abi 'Aqrab dan Muslim bi Mikhqar.

Salah satu hadis dari Asma binti Abu Bakar yang terkait dengan aktivitas menyiapkan perbekalan adalah:

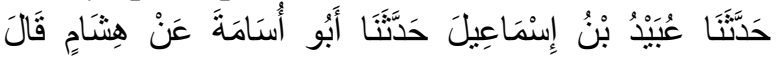

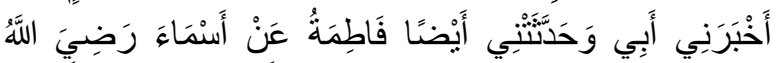

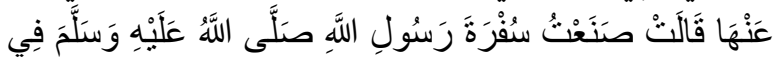

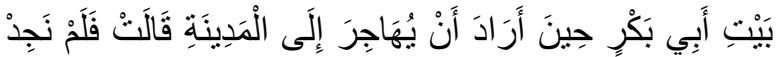

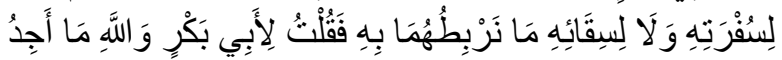

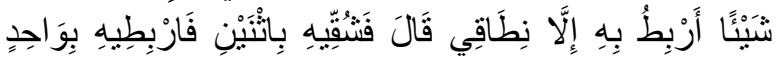

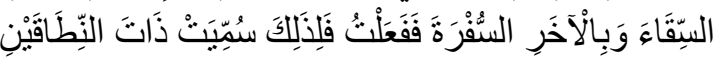

\section{Beternak dan Berkebun}

Disamping menyiapkan perbekalan, pernah mengikuti peperangan, Asma binti Abub Bakar juga melakukan aktivitas seperti beternak dan berkebun. Kedua aktivitas tersebut bukanlah hal yang tabu dilakukan oleh perempuan pada masa Nabi Muhammmad, suatu hal yang justru berbanding terbalik dengan kondisi perempuan Arab saat ini. Hadis yang menjelaskan tentang aktivitas berternak dan berkebun yang dilakukan oleh Asma binti Abu Bakar adalah sebagai berikut:

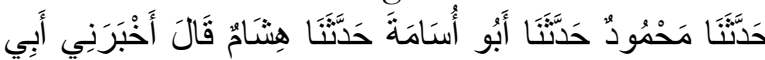

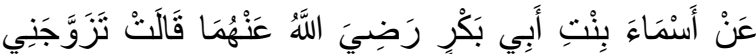

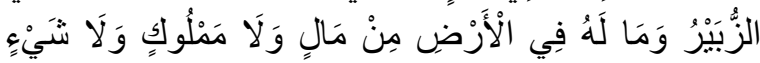

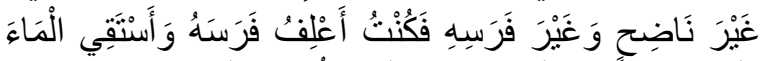

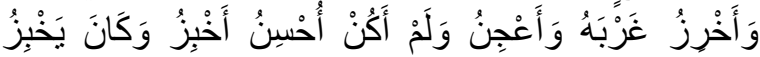

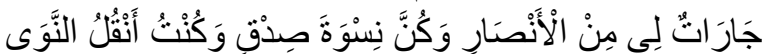

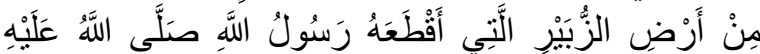

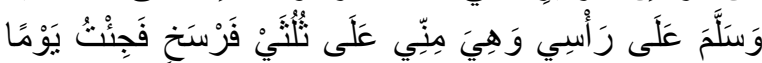

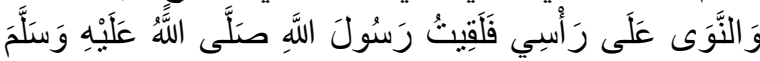

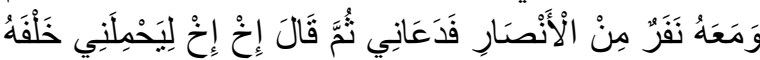

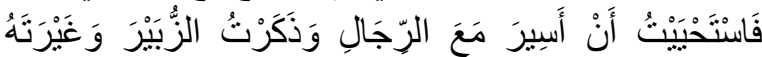

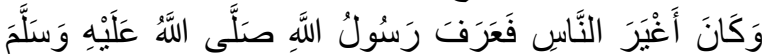

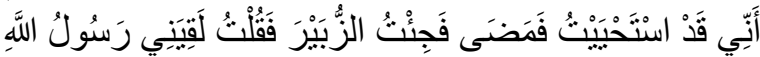

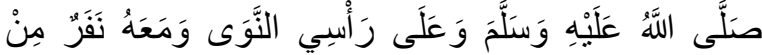

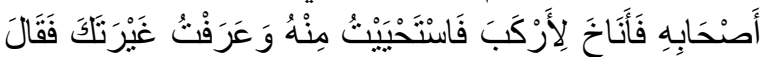

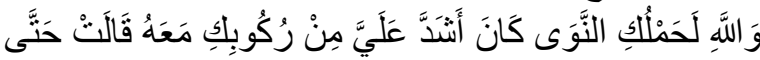

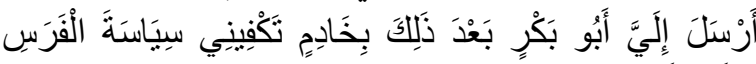

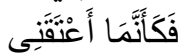

\section{Menyamak Hewan}

Menyamak hewan juga merupakan aktivitas yang biasa dilakukan oleh perempuan pada masa Nabi Muhammad, diantara sahabat yang melakukan aktivitas ini adalah Asma bnti Umais. Asma binti Umais meriwayatkan 24 hadis dari Rasulullah, beberapa periwayat yang meriwayatkan hadis dari beliau adalah Abu Bakar bin Abd Rahkab bin Haris, Ummu 'Aun binti Muhammad bin Ja'far, Zaid bin 'Athiyah, Sa'id bin Musayyab, Abdullah bin Ja'far, Abdullah bin Syaddad, 'Ubaid bin Rafa'ah, Urwah bin Zabir, Fatimah binti Ali, Qasim bin Muhammadm Mujahid bin Jabar, dan Ma'mar bin Mutsanna. 
Salah satu hadis yang diriwayatkan oleh Asma binti Umais yang menjelaskan tentang aktivitasnya menyamak hewan adalah :

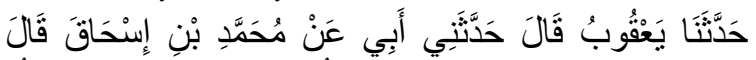

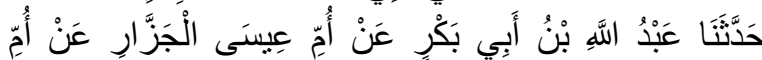

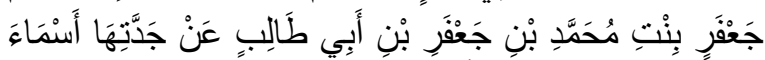

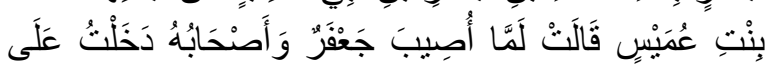

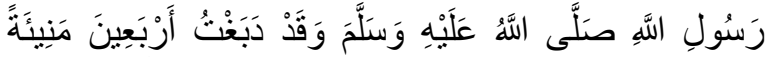

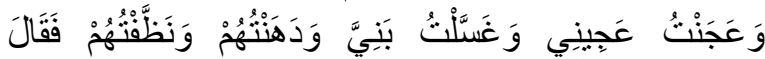

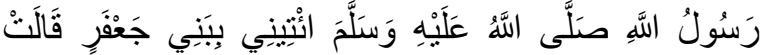

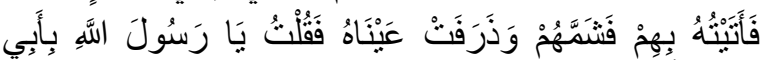

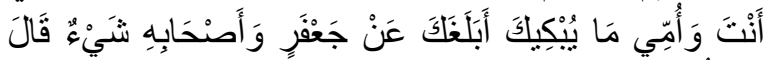

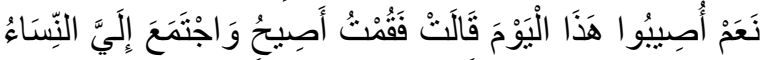

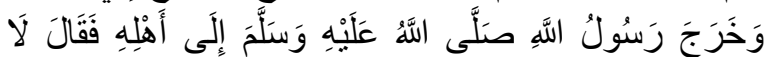

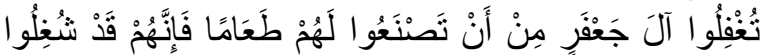

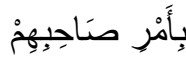

\section{Perias pengantin}

Merias pengantin adalah salah satu profesi yang telah dilakukan oleh perempuan pada masa Nabi Saw.Salah satu sahabat perempuan yang berprofesi sebagai perias pengantin adalah Asma binti Yazid. Asma binti Yazid merias Aisyah ketika akan menikah dengan Nabi Saw. Diceritakan bahwa Asma merias Aisyah, kemudian tibatiba Nabi Saw datang dan duduk di sampingnya, lalu beliau diberi semangkuk susu, Nabi meminumnya dan memberikan (sisanya) kepada 'Aisyah. 'Aisyah pun malu sambil menundukkan kepala."Kemudian Asma' berkata, "Ambillah dari tangan Rasulullah shallallahu 'alaihi wasallam."Asma' melanjutkan, "Aisyah kemudian mengambil dan meminumnya. Kemudian Nabi Saw berkata kepadanya: "Berikanlah kepada saudaramu."Kemudian Asma duduk sambil menaruh (semangkuk susu) di atas pangkuannya. Lalu dia memutar ujung dari bekas minumnya Nabi shallallahu 'alaihi wasallam. Lantas Nabi shallallahu 'alaihi wasallam bersabda kepada para wanita yang berada di sampingnya: "Berikanlah kepada mereka." Kami mengatakan, "Kami tidak berselera." Maka Nabi Saw bersabda: "Janganlah kalian menggabungkan rasa lapar dengan kebohongan, apakah kamu mengatakan 'Aku tidak berselera' padahal kamu mau?".

Peristiwa ini direkam oleh Asma binti Yazid dalam hadis-hadis yang dia riwayatkan, di ataranya adalah sebagai berikut: ${ }^{22}$

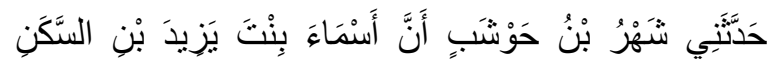

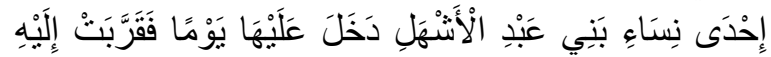

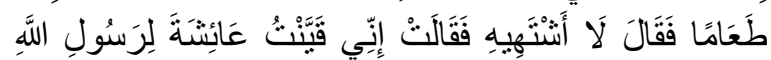

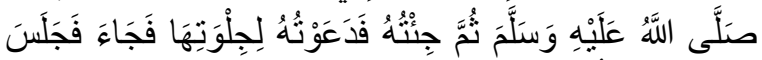

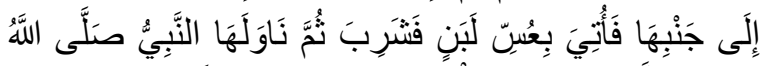

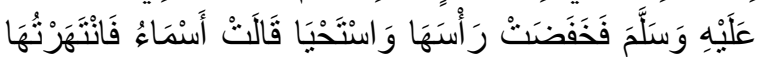

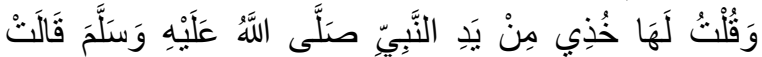

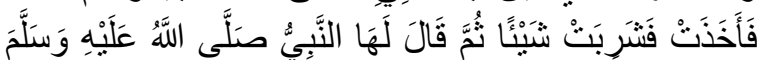

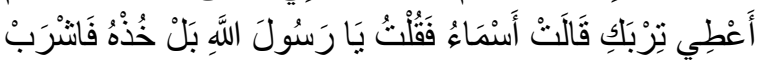

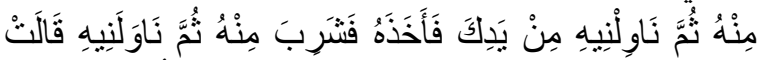

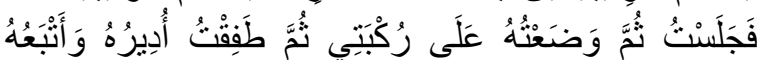

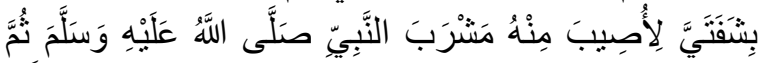

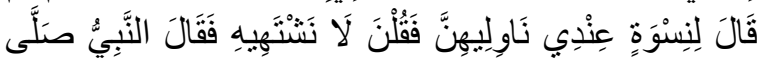

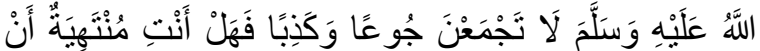

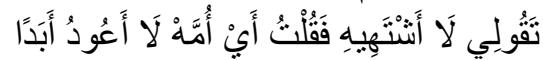

\section{Ahli pengobatan dan bidan.}

Salah satu sahabat perempuan yang ahli dalam pengobatan dan juga berprofesi sebagai bidan adalah Salma.Salma juga merupakan pelayan Nabi Saw.Dia juga yang membantu Khadijah melahirkan putraputrinya. ${ }^{23}$ Dalam hadis-hadis yang diriwayatkannya diceritakan bagaimana Salma bayak terlibat terutama merawat dan membantu mengobati Nabi Saw dan putrinya Fatimah.Diceritakan dalam riwayat bahwa apabila Rasulullah Saw terluka atau terkena koreng, maka dia memolesinya dengan inai."Salma juga merupakan orang yang merawat Fatimah ketika Fatimah sakit yang membawanya pada kematian.Mulai dari

${ }^{22}$ Musnad Ahmad, nomor hadis 26309

23 Aisyah Bewley, Ibid., hlm 140 
memandikan, memakaikan baju hingga permintaan terakhir Fatimah jelang kematiannya, yakni meletakkan tempat tidur Fatimah di tengah-tengah rumah dan menghadap kiblat, semua ini dilakukan oleh Salma. Semua ini terekam dalam hadis-hadis yang diriwayatkannya, diantaranya adalah: ${ }^{24}$

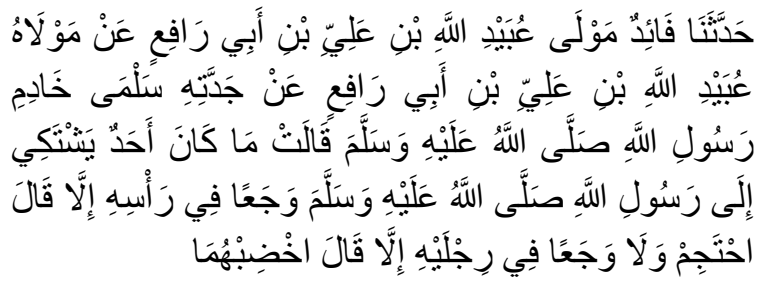

\section{Pelayan}

Beberapa sahabat perempuan mereka adalah pelayan Nabi Saw, seperti Barkah binti Tsa'labah atau yang dikenal dengan Ummu Aiman.Ummu Aiman adalah pelayan setia sejak ibunda Nabi Saw masih belum wafat. Setelah wafatnya sang ibu, Ummu Aiman tetap menjadi seorang yang setia melayani Nabi Saw. Hal ini terekam di dalam hadis-hadis yang diriwayatkannya, di mana diceritakan Ummu Aiman mengayak gandum dan menjadikannya roti, sebagaimana hadis berikut: ${ }^{25}$

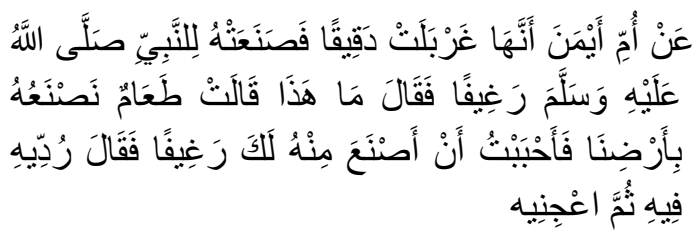

Sedangkan Ummu Ayyash adalah pelayan dari putri Nabi Saw Ruqayyah, sehingga tidak mengherankan jika Ummu Ayyash turut serta membantu Nabi Saw dalam beberapa hal dan peristiwa ini juga terekam di dalam hadis yang dia riwayatkan.

${ }^{24}$ Sunan Ibnu Majah, kitab al-Hina' nomor hadis 3493, Musnad Ahmad, kitab Hadits Ummu Salma Radliyallabu' anba, nomor hadis 26334

${ }^{25}$ Sunan Ibnu Majah, kitab al-At'imah nomor hadis 3327, Musnad Abmad, kitab min Musnad alQabail nomor hadis 26098

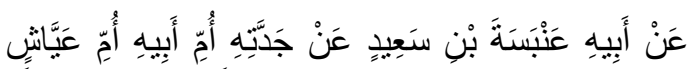

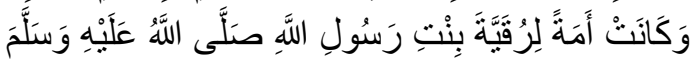

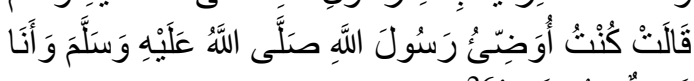

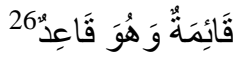

\section{Pengasuh Cucu Nabi Saw}

Lubabah adalah orang kedua yang masuk Islam setelah Khadijah.Lubabah atau dikenal dengan Ummu Fadhl ini merupakan ibu susuan dan pengasuh dari Husain, cucu Nabi Saw.Hal inilah yang menjadikan hubungannya dengan keluarga Nabi Saw cukup dekat. Diceritakan ketika Lubabah sedang menyusui Hasan atau Husain, kemudian datanglah Rasulullah shallallahu 'alaihi wasallam dan berbaring di tempat yang agak menurun, kemudian beliau menaruh (Hasan atau Husain) di atas perutnya, tapi kemudian Hasan kencing di atas perut beliau, saya melihat kencingnya mengalir di atas perutnya sehingga Lubabahpun bangun mendekati untuk menuangkan (air) kepadanya, kemudian Nabi Saw menyatakan bahwa kencing bayi laki-laki cukup diperciki dengan air, sedangkan kencing bayi perempuan harus dicuci. Hampir semua hadis yang diriwayatkan oleh Lubabah binti Haris ini menunjukkan perannya sebagai pengasuh dari Hasan Husain. Salah satu hadis yang diriwayatkannya adalah sebagai berikut:

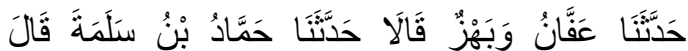

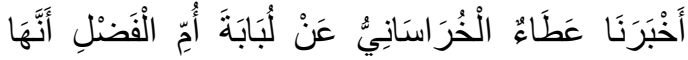

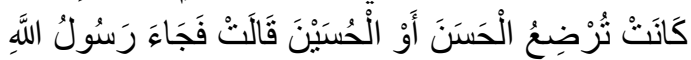

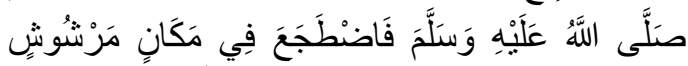

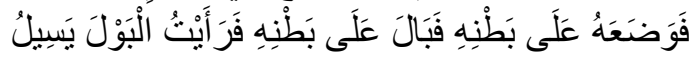

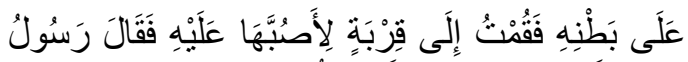

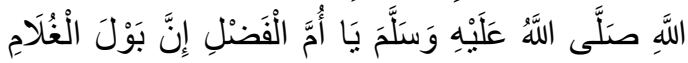

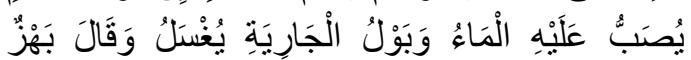

${ }^{26}$ Sunan Ibnu Majah, nomor hadis 386. 


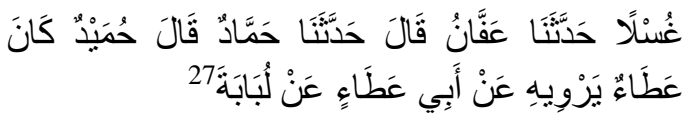

Dari sini kemudian, maka terlihat bahwa para sahabat perempuan pada masa Nabi tidak hanya berperan pada wilayah domestik (sebagai ibu rumah tangga, yang hanya mengasuh anak dan melayani suami), tetapi mereka juga tampil di wilayah publik.Mereka juga terlibat dalam berbagai peperangan, sebuah aktifitas yang selama ini identik dengan kaum laki-laki, pendidikan, pertanian, perkebunan dan lain sebagainya.

\section{Memahami Peran Sahabat Perempuan dan Hadis-hadis yang Mereka Riwayatkan serta Implikasinya bagi Pemahaman Hadis}

Tidak bisa dipungkiri bahwa peran sahabat perempuan pada masa Nabi Saw tidak bisa dipandang sebelah mata.Apa yang tercermin dari hadis-hadis yang diriwayatkan oleh para sahabat perempuan periwayat hadis memperlihatkan bahwa hadis sebagai sebuah teks yang dipercaya sebagai teks ajaran Islam bukanlah teks yang steril dari pergulatan sejarah. Sejarah disini tidak hanya berupa konteks masyarakat Arab, konteks Nabi Saw sebagai pembawa berita utama tetapi juga konteks subyektifitas para periwayat hadis.Peran para sahabat di dalam masyarakat tercermin dari periwayatan hadis-hadisnya, karena sebagai periwayat pertama, sudah semestinya dia melihat dan mengalami peristiwa tersebut secara langsung bersama Nabi Saw. Sebagaimana yang dinyatakan oleh Khaleed Abou Fadl bahwa setiap hadis dinisbatkan dan disandarkan kepada Nabi merupakan hasil akhir dari sebuah proses kepengarangan. Secara Konkrit, setelah menyelidiki keseluruhan kondisi historisnya, seseorang mungkin dapat mengambil sebuah

${ }^{27}$ Musnad Ab\{mad, nomor hadis 25643 kesimpulan bahwa sebuah riwayat tertentu memberitahukan banyak hal tentang Nabi, atau seseorang mungkin akan menyimpulkan bahwa sebuah riwayat lebih banyak memberitakan tentang kondisi historis para perawi daripada hal lainnya. Dengan demikian, keberadaan proses kepengarangan ini mau tidak mau akan memaksa seseorang untuk memahami hadis Nabi sebagai sejarah. ${ }^{28}$

Dari sini sebenarnya, merujuk pada Abou Fadl, sesungguhnya banyak pengarang yang terlibat dalam kemunculan suatu riwayat atau sebuah hadis. Masing-masing dari pengarang itu dapat memerankan fungsi yang sama, namun dapat juga memerankan fungsi yang berbeda-beda, tergantung pada konteksnya. Sebagaimana yang dinyatakannya:

"Teks bisa dibuat oleh satu pengarang atau lebih, tetapi rincian dari pengarangnya tidak kemudian hanya terbatas pada orangorang yang namanya tercantum dalam sampul buku. Terutama bila buku tersebut berkenaan dengan tradisi oral seperti sunnah Nabi, seseorang harus berhadapan dengan kemungkinan yang sangat terbuka bahwa proses kepengarangan dan bukannya seorang pengarang berada di balik proses tersebut. Bahkan yang dikatakan ditulis oleh satu orang pengarang dan hanya dihubungkan dengan penulisnya yang seorang itu dalam kenyataanya diproduksi oleh banyak intelektual dan nilainilai sosial normatif yang membentuk pemikiran si pengarang. ${ }^{29}$

Teks tersusun dari sub-sub teks karena lambang seringkali mengandung sub-sub lambang dan entitas juga mengandung sub-sub entitas. Lebih jauh lagi, pengarang sebuah teks pastilah bagian dari lawan baca tersebut, sejauh ia mengenali dan memahami lambang-lambang teks, lawan baca teks itu ikut ambil bagian

${ }^{28}$ Ibid.,hlm 130-131.

${ }^{29}$ Khaleed Abou Fadl, Melawan "Tentara Tuban": Yang berwenang dan yang sewenang-wenang dalam Wacana Islam, (Jakarta: Serambi, 2003), hlm 105. 
dalam proses kepengarangan. Dalam pengertian ini, sebuah teks bisa memiliki beragam pengarang, yaitu pengarang historis yang menciptakan teks, pengarang revisi yang menyunting, mengubah dan menuangkan kembali teks tersebut, dan pengarang interpretasi yang menerima dan menciptakan makna dari lambang-lambang yang membentuk teks. Beragam pengarang ini tidak memerankan peran dan fungsi yang sama, namun peran dan fungsi mereka berubah mengikuti konteks tertentu. ${ }^{30}$

Dari apa yang ditulis oleh Abou Fadl, ia ingin menyatakan bahwa Nabi bukanlah dunia Tuhan dan Nabi merupakan manusia biasa dan karenanya tunduk pada proses sejarah. Nabi berinteraksi dengan sejarah bukan sebagai Tuhan, melainkan sebagai bagian dari dinamika kehidupan manusia normal.Dengan demikian dapat dikatakan bahwa perintah moral dan normatif Nabi muncul dalam konteks sejarah.Pesan moral Nabi disajikan dan diuji oleh konteks historisnya, tapi konteks tersebut tidak dapat dan tidak menampung seluruh kebenaran dan kenyataan pengalaman moral Nabi. Oleh karena itu, hadis sebagai warisan dari Nabi tidak dapat diletakkan diluar konteks campur tangan dan proses kepengarangan manusia. Maka ketika menganalisis aktivitas komunikasi interpretasi yang terbentuk disekitar teks sunnah, persoalan yang muncul adalah sejauh mana komunitas interpretasi ini mencerminkan, memahami, atau memasukkan konteks historis proses kepengarangan. Karena komunitas interpretasi harus mempertimbangkan proses proses kepengarangan beserta seluruh perubahan urutan historisnya untuk memahami keseimbangan yang patut antara pengarang historis-yang dalam hal ini adalah Nabi- dan beragam suara pengarang yang

\footnotetext{
${ }^{30}$ Khaleed Abou Fadl, Atas Nama Tuban...., hlm 153-154.
}

menyajikan konteks bagi pengarang historis tersebut. $^{31}$

Gagasan tentang proses kepengarangan itu memainkan peranan penting dalam memahami penafsiran yang dilekatkan pada sebuah riwayat tertentu. Bahkan jika kita berasumsi bahwa Nabi sebenarnya memang telah membuat pernyataan tersebut tidak sampai kepada kita dalam sebuah kevakuman.Kata-kata dan ungkapan tersebut sering kali sampai ke tangan kita beserta seluruh makna dan rangkaian makna yang dilekatkan kepadanya.Hal ini tentu juga semakin memperkuat asumsi bahwa sahabat seharusnya tidak bisa dilepaskan dari kritik.Salah satu contoh dari subyektifitas periwayat hadis adalah hadis-hadis misoginis ${ }^{32}$ yang selama ini menjadikan perempuan seolah sebagai makhluk kelas dua, ternyata hanya sedikit sekali yang diriwayatkan oleh periwayat perempuan. Diantara hadis-hadis misoginis tersebut misalnya, Hadis tentang teologi seperti hadis tentang kebanyakan perempuan yang masuk neraka, hadis tentang perempuan diciptakan dari tulang rusuk, perempuan kurang akal dan agama, perempuan disimbolkan seperti setan, perempuan sebagai penyebab dan sumber bencana, perempuan merupakan fitnah dunia. Kemudian hadis

${ }^{31}$ Ibid.,hlm 162-163.

${ }^{32}$ Misoginis (Misogynist) merupakan istilah yang berasal dari bahasa Inggris "misogyny" yang berarti "kebencian terhadap wanita".Jhon Echols dan Hassan Shadily, Kamus Inggris-Indonesia (Jakarta: Gramedia, 1986), hal. 382. Klaim adanya unsur misoginis dalam hadis dipopulerkan oleh Fatima Mernissi, (seorang penulis, sosiolog, dan feminis kelahiran Maroko tahun 1940. Ia kuliah tentang ilmu politik di Universitas Mohammed V Rabat, Maroko, dan melanjutkan pasca sarjana di Universitas Sorbonne, Perancis dan Universitas Brandeis, Amerika Serikat, hingga mendapatkan gelar doktor tahun 1973). Dalam bukunya Women and Islam: An Historical and Theological Enquiry ${ }^{32}$ Mernissi menunjukkan hadis-hadis yang dianggap membenci dan merendahkan derjat perempuan. Kajian hadis misoginis menjadi topik yang selalu hangat dibahas dewasa ini, seiring dengan pembahasan kesetaraan gender dan hak-hak asasi manusia dalam pelbagai aspek kehidupan yang berimbas pula pada pembahasan agama. 
tentang ibadah, seperti najis kencing perempuan dua kali lipat dibandingkan lakilaki, perempuan tidak bisa menjadi imam bagi laki-laki, perempuan lebih baik shalat di rumah, perempuan berpuasa harus dengan izin suami, shaf shalat perempuan harus di belakang laki-laki, perempuan pergi haji harus bersama muhrim, perintah untuk sujud kepada suami. Hadis-hadis tentang muamalah, misalnya hadis tentang tidak boleh menjadi seorang pemimpin, perempuan boleh dipoligami, warisan perempuan separo dari laki-laki, perempuan yang tidak memenuhi panggilan suami akan dilaknat, dan larangan menerima tamu tanpa seizin suami. Hanya sebagian kecil dari hadis misoginis tersebut yang melibatkan periwayat hadis perempuan. Disinilah menurut penulis independepsi seorang periwayat perempuan untuk memilih riwayat-riwayat yang akan diriwayatkan menemukan relevansinya. Dengan demikian maka, unsur periwayatan tidak bisa dilepaskan dari unsur subyektifitas dari sahabat yang meriwayatkan, karena mereka hanya meriwayatkan hadis sesuai dengan apa yang mereka ketahui dan ingin riwayatkan.

Selain itu kajian tentang hadis-hadis yang diriwayatkan oleh periwayat perempuan ini setidaknya memberikan rujukan bagi konstruksi gender di dalam masyarakat muslim, dimana keterlibatan mereka dalam ruang publik dan dalam menyelesaikan persoalan kemasyarakatan bukanlah hal yang tabu. Aksi protes yang dilakukan perempuan juga menjadi hal yang biasa terjadi di dalam dinamika sosial masyarakat.Sebuah gambaran bagi sebuah masyarakat yang sangat moderat.Tanpa visi dan misi yang revolusiner dan diiringi dengan aksi nyata dalam sebuah gerakan sosial oleh Nabi Saw, tidak mungkin ajaran Islam bisa dengan mudah dikenal dan menyebar di seluruh penjuru dunia. Dengan demikian, upaya untuk mengembalikan posisi perempuan sebagaimana era Nabi Saw bukanlah dengan membatasi peran mereka di ruang publik, tetapi justru dengan memberikan kesempatan, keamanan dan kenyamanan bagi perempuan untuk berkiprah di ruang publik. Memposisikan mereka sebagai subyek dan bukan sebagai obyek. Memandang mereka secara sosial dan intelektual yang bisa memberikan kontribusi bagi masyarakat yang luas, bukan hanya sekedar memandang mereka secara seksual. Posisi setara (egaliter) tanpa memandang perbedaan jenis kelamin dan status sosial di dalam masyarakat muslim inilah yang menjadi konsepsi ideal dari ajaran Islam yang sesungguhnya. Karena hanya sisi ketaqwaanlah yang akan membedakan manusia di hadapan Tuhannya.

\section{Penutup}

Demikianlah, makalah singkat ini mengungkapkan bagaimana keterkaitan antara situasi dan kondisi para sahabat perempuan yang berpengaruh terhadap hadis yang diriwayatkannya.Hadis ini kemudian yang menjadi sumber hukum kedua bagi umat Islam saat ini.Karenanya, pemahaman terhadap hadis tidaklah cukup memadai tanpa melihat lebih jauh pada periwayat-periwayatnya, karena merekalah yang mentransformasikan informasi dari Nabi Muhammad.Jadi, meski hadis diyakini bersumber dari Nabi Saw, tetapi kehadiran periwayat juga memberikan "andil" terhadap kemunculan hadis.Hadis-hadis yang sampai pada sahabat tentu tidak bisa lepas dari situasi dan kondisi para sahabat itu sendiri, karena intensitas para sahabat bertemu dengan Nabi Saw dan dalam peristiwa apakah kebersamaan mereka sangat mempengaruhi hadis-hadis yang diriwayatkannya.Dengan demikian maka, penelitian terhadap para sahabat periwayat hadis penting untuk dilakukan. Jika selama ini tradisi dalam jarb wa ta'dil mengecualikan thabaqat sahabat untuk diteliti karena dianggap telah memiliki kredibilitas tinggi, maka menurut penulis, justru kalangan sahabat harus diteliti terutama keterkaitannya dengan konteks dan peristiwa 
pada masa Nabi Saw. Hal ini karena para sahabatlah yang bertemu langsung dengan Nabi Saw dan pemberi informasi pertama tentang hadis.

Makalah singkat diatas juga membuktikan bahwa pada masa Nabi Muhammad sahabat perempuan turut berperan dalam masyarakatnya.Tidak hanya pada wilayah domestik sebagaimana yang telah diasumsikan oleh banyak kalangan.Keberadaan perempuan di wilayah publik dan kiprah mereka memperlihatkan bagaimana posisi perempuan pada masa Nabi Saw.

\section{Daftar Pustaka}

Abou Fadl, Khaleed, Melawan "Tentara Tuban" : Yang berwenang dan yang sewenang-wenang dalam Wacana Islam, Jakarta: Serambi, 2003.

--1 Atas Nama Tuban; Dari Fikih Otoriter ke Fikih Otoritatif, Jakarta: Serambi, 2003.

Abbott, Nabia, Aishab: The Beloved of Muhammad, Chicago: University of Chicago, 1942.

Abd Karim, Khalil, Shadwa al-Rababab bi-Abwal Mujtama' al-Shahabah: al-Shahabah wa alShahabah, Kairo: Sina li al-Nasyar, 1997.

Abdelaty Haredy,Mohsen, Female Transmission of Hadith in the Mamluk Period : an annotated edition and study of Ibn Hajar's Mu'jam AsySyaikhah Maryam, Doctoral Thesis, Leiden University, tahun 2014.

Abdullah (ed.), Irwan,Sangkan Paran Gender, (Yogyakarta: Pustaka Pelajar dan Pusat Penelitian Kependudukan UGM, 1997.

Abrar, Fatahillah, "Peran Fatimah Az-Zahra sebagai sahabiyat dalam meriwayatkan hadis serta hadis-hadis yang diriwayatkannya," skerispi UIN Sunan Kalijaga Yogyakarta, 2012 .

Abu Dawud, Imam, Sunan Abi Dawnd, jilid I, Beirut: Dar al-Kutb al-Ilmiyyah, T. th.

Abu Syuqqah, Abdul Halim, Kebebasan Wanita, Jakarta: Gema Insani Press, 1998.
Abu Zahw, Muhammad, al-Hadis wa alMuhaddisun, Mesir: Mathba'ah Misr, t.th.

Ahmad, Leila, Wanita dan Gender dalam Islam: Akar-akar Historis Perbedatan Modern, terj. M.S Nasrullah, Jakarta: Lentera Basritama, 1992.

Akram Nadwi, Mohammad,al-Mubaddithat: the

Woman Scholar in Islam, Istambul:

Interface publiation, 2007.

A Mahzun, Muhammad, Tahqiq Mawaqif alShahabah fi al-fitnah, Riyadh: Maktabah al-Kaustar, 1994.

Amin Ahmad, Fajrul Islam, Kairo: Maktabah al-Nahdah al-Misriyyah, 1997. Dhuba al-Islam, Kairo: Maktabah al-Nahdah, 1956.

Anam, Wahidul, " 'Adalah al-Shahabah dalam Studi Hadis, Kemunculan, Pelembagaan dan Pembongkaran, disertasi, Program Pasca Sarjana UIN Sunan Kalijaga Yogyakarta, tahun 2014.

al-Asqalany, Ahmad bin Ali Ibn Hajar, Fatbul Bari fi Syarbi Shabih Bukhari, Beirut: Dar al-Ma'arif, t.th.

Tamyiz al-Sahabah, Mesir: al-Maktabah al-Tijjariyah, 1358.

al-Tahdrib, Juг XII, Beirut: Dar Shadir, $1327 \mathrm{H}$.

Athir, Ibn, Usul al-Ghabah fi Ma'rifati alshahabat, Kairo: al-Sha'ab, 1970.

Azami, Mustafa Manhaj al-naqd ind alMubaddithin: Nash'atuh wa tarikhub, Riyadh: al-Taba'ah al-Arabiyah alSa'udiyah al-Mahdudah, 1982

Berger, Peter L, The Sacred Canopy; Elements of $A$ Sociological Theory of Religion, (New York: Doubleday, Garden City, 1967.

\section{---_Kabar dari Langit; Makna} Teologi dalam Masyarakat Modern, Jakarta: LP3ES, 1987.

Bintusy Syathi', Aisyah Abdurrahman, Nisaun Naby, Alaibishshalatu Wassalaamu, terj. Chadidjah Nasution, Jakarta: Bulan Bintang, 1974.

Banatun Naby Alaibis Shalatu Wassalam, 
terj. Chadidjah Nasution, Jakarta: Bulan Bintang, 1975.

Al-Bukhari, Muhammad Ismail, Shabih alBukhari, jilid 6, T.tp: Dar wa Mathabi' al-Sya'b, T.th.

Coulson, Noel J, A History of Islamic Law, Edinburg: Edinburg University Press, 1964.

Danarta, Agung, "Perempuan Periwayat Hadisdalam al-Kutub al-Tis'ab", Disertasi, Program Pasca Sarjana UIN Sunan Kalijaga Yogyakarta, 2007.

Giddens, Anthony,The Constitution of Society: Outline of the Theory of Structuration, Cambridge: Polity Press, 1984.

Goldziher, Ignaz, Introduction to Islamic Theology and Law, New York: Princeton University Press, 1981.

-, Muslim Studies, trans. C. R. Barber and S. M. Stern, Chicago: Aldine, 1968.

Hasanah, Amalia, "Rawi Wanita dalam Periwayatan Hadis ; Studi Terhadap Rawi Sahabat Wanita dalam kitab Sabih al-Bukhari", Skripsi UIN Sunan Kalijaga Yogyakarta, 2005.

Ibn Hanbal, Ahmad, Musnad al-Imam Ahmad ibn Hanbal, jilid VI, Beirut: Dar alFikr, T.th.

al-Iraqi, Abd al-Rahman bin al-Husayn, Fath al-Mughth Sharb Fath alfiyat al-hadis, jilid4, Beirut: Dar Kutub al-Ilmiyah, t.th.

Jabali, Fuad,The Companions of the Prophet: $A$ Study of Geographical Distribution and Political Alignments, Canada: Institute of Islamic Studies McGill University Montreal, 1999.

Jones, Pip, Introducing Social Theory, terj. Achmad Fedyani Saifuddin, cet-II, Jakarta: Yayasan Pustaka Obor Indonesia, 2010.

Juynboll, G. H. A, The Authenticity of the Tradition Literature Discussions in Modern Egypt, terj. Ilyas Hasan, Bandung : Mizan, 1999.

al-Khatib, Muhammad 'Ajjaj, al-Sunnah Qabl alTadwin, Kairo: Maktabah Wahbah, 1963.
Ulumubu Wa Mustalabubu, Beirut: Dar Al-Fikr, 1989.

Lutfi, Huda, "As-Sakhāwī's Kitāb an-Nisā’’", Cambridge University Press, 1975.

Majah, Abu Abdullah Muhammadi bin Yazid ibn, Sunan Ibn Majah, Beirut: Dar alFikr, t.th.

McGuire, Meredith B,Religion: The social Context, California: Wadsworth Publishing Company, 1981.

Mernissi, Fatimah, Wanita dalam Islam, terj. Yaziar Radianti, Bandung: Pustaka, 1994.

Ratu-ratu Islam yang Terlupakan, terj. Rahmani Astuti dan Erna Hadi, Bandung: Mizan, 1994.

Muhanif, Ali (ed.), Perempuan dalam Literatur Klasik, Jakarta: Gramedia, 2002.

Muslim, Ibn Hajjaj, Shabih Muslim, julid V, Kairo: al-Halabi wa Auladuh, T.th.

An- Nasa'i, Sunan al-Nasa'i, Bab Bawlu alJariyah (Riyad: Maktabah al-Ma'arif, t.th).

Palmer, Richad E,Hermeneutika : Teori Baru Mengenai Interpretasi, Yogyakarta: Pustaka Pelajar, 2003.

Rayyah, Abu, Adwa 'ala al-Sunnab alMubammadiyah aw Difa'an al-Hadis, Mesir: Dar al-Ma'rifah, 1964.

Șālih Ma 'tūq, Jubūd al-Mar' ab fì Riwàyat alHadith: al-Qärn ath-Thāmin al-Hijrì, Beirut: Dār al-Bashā' ir al-Isālmiyyah, 1997.

-------' 'Ilm al-Hadith fi Makkah alMukarramah kbilāl al-'Aṣr al-Mamlūkì (648 AH-923 AH), Beirut: Mu'assast ar-Rayyān, 2000.

Sanders, Paula, review of The Transmission of Knowledge in Medieval Cairo, by Jonathan Berkey, Speculum 70, no. 3, July 1995: 580.

Sayeed, Asma," Shifting Fortunes : Women and Hadìth Transmission in Islamic History (first to eighth centuries)", doctoral dissertation, Princeton University, 2005. -, "Women in Hadīth Transmission: Two Case Studies from Mamluk Damascus," Studia Islamica 95, (2002, hlm 71-94. 
Woman and Transmissions of

Religious Knowladge in Islam, USA:

Camridge University, 2015.

Soekanto, Soerjono, Beberapa Teori Sosiologi tentang Struktur Masyarakat, Jakarta: CV Rajawali, 1983.

al-Shalah, Ibn, Ulum al-Hadis, Beirut: Dar alFikr al-Mu'asir, 1986.

Shalih, Subhi al-, Ulum al-Hadis wa Musthalabuhu, Beirut: Dar al-Ilm li Malayin, 1977

Siddiqi, M. Z,Hadīth Literature, edited and revised by Abdul Hakim Murad Cambridge: Islamic Texts Society, 1993.

al-Siba'I, Mustafa, al-Sunnah wa Makanatuba fi al-Tashri' al-Islamy, Mesir: al-Dar alQawmiyah, 1966.

al-Suyuthi, Jalal al-Din,Tadrib al-Rawi fi Sharh Taqrib al-Nabawy, Beirut: Dar Ihya alSunnah al-Nabawiyah, 1979.

Syamsuddin, Sahiron, Hermeneutika dan Pengembangan Ulumul Qur'an, Yogyakarta: Nawesea, 2009.

Tirmidzi, Abu Isa Muhammad ibn Isa al-, Sunan al-Tirmidzi wa Huwa al-Jami' alShabih, dalam CD ROM: Mausu'at alHadis al-Syarif, Beirut: Global Islamic Software Company.

Umar, Nasaruddin, Argumen Kesetaraan Gender dalam Perspektif Al-Qur'an, Jakarta: Paramadina, 1999.

Zain, Muhammad, "Profesi Sahabat Nabi dan Hadis yang diriwayatkannya, Tinjauan Sosio-Antropologis," Disertasi Program Pasca Sarjana UIN Sunan Kalijaga Yogyakarta, 2007. 